\title{
EFEKTIVITAS MODEL PEMBELAJARAN KOOPERATIF TIPE NUMBERED HEAD TOGETHER (NHT) TERHADAP HASIL BELAJAR IPA KELAS III DI SD NEGERI GUNUNGSAREN SRANDAKAN BANTUL YOGYAKARTA TAHUN AJARAN 2015/2016
}

\author{
Sapta Indarsih dan Martalia Ardiyaningrum \\ Pendidikan Guru Madrasah Ibtida'iyah STIA Alma Ata \\ Email: martaliayudhono87@gmail.com
}

\begin{abstract}
ABSTRAK
Penelitian ini bertujuan untuk mengetabui perbedaan hasil belajar IPA kelas III di SD N Gunungsaren antara pembelajaran yang menggunakan model pembelajaran kooperatif tipe Numbered Head Together (NHT) dengan pembelajaran model konvensional dan mengetahui efektifitas pembelajaran kooperatif tipe Numbered Head Together (NHT) terbadap hasil belajar IPA siswa kelas III di SD N Gunungsaren. Populasi penelitian ini adalah seluruh siswa kelas III SD N Gunungsaren, dengan sampel penelitian adalah kelas III B yang memperoleb perlakuan Model Pembelajaran Kooperatif tipe NHT dan kelas III A dengan model konvensional. Analisis data meliputi uji Normalitas, Homogenitas, dan Uji Mann-Whitney U-Test dengan bantuan program SPSS 16.

Hasil penelitian menunjukkan babwa adanya perbedaan hasil belajar kelas yang menggunakan model pembelajaran kooperatif tipe Numbered Head Together (NHT) dengan hasil belajar kelas konvensional pada pembelajaran IPA kelas III di SD N Gunungsaren Srandakan Bantul. Model pembelajaran kooperatif tipe Numbered Head Together (NHT) ini efektif digunakan karena rata-rata yang didapatkan di kelas eksperimen 95 dan terdapat 100\% siswa yang mendapatkan nilai di atas KKM (Kriteria Ketuntasan Minimal) dari jumlah siswa.
\end{abstract}

Kata kunci:

\begin{abstract}
The aims of this study are to determine: 1) the differences of the learning outcome between cooperative learning model Number Head Together (NHT) and conventional learning model 2) the effectiveness of cooperative learning model Number Head Together (NHT) on the learning outcome of science (IPA) subject in the third grade student of SDN Gunungsaren. The population of this research are the third grade students of SDN Gunungsaren and the samples are students in the class IIIB as intervention group (NHT) and IILA as the control group (conventional). Data were analized using Mann-Whitney U-Test with SPSS 16.

This research shows that there is a significant difference between learning outcomes in IPA subject from intervention group and control group. Cooperative learning model Number Head Together (NHT) has an effective impact on student's learning outcomes for average score obtained were 95 and 100\% student pass the KKM (Kriteria Ketuntasan Minimal).
\end{abstract}

\section{Keyword:}

\section{PENDAHULUAN}

Di zaman globalisasi ini pendidikan sangat penting, dikarenakan dengan adanya pendidikan akan melahirkan generasi-generasi penerus bangsa yang nantinya akan menjadi pemimpin bangsa Indonesia selanjutnya. Tujuan pendidikan nasional di dalam Tap MPR No. II/1998 dikatakan: "Pendidikan nasional bertujuan untuk meningkatkan kualitas manusia Indonesia, yaitu manusia yang beriman dan bertakwa terhadap Tuhan Yang Maha Esa, berbudi pekerti luhur, berkepribadian, berdisiplin, bekerja keras, 
tangguh, bertanggung jawab, mandiri, cerdas, dan terampil serta sehat jasmani dan rohani."1

Tujuan pendidikan nasional menjelaskan bahwa pendidikan merupakan suatu usaha yang sengaja direncana oleh orang yang berkompeten di bidang pendidikan untuk membantu mengembangkan potensi dan kemampuan anak didik, sehingga di saat dewasa nanti akan dapat dimanfaatkan untuk masa depannya.

Dalam mencapai tujuan pendidikan nasional membutuhkan peran guru sebagai fasilitator dalam proses pembelajaran. Guru tidak lagi menjadi satu-satunya sumber ilmu, karena perkembangan sains dan teknologi memungkinkan peserta didik memperoleh ilmu dari berbagai sumber seperti internet (e-journal \& e-book), program televisi, gambar, audio, dan sebagainya. Fungsi guru sebagai fasilitator lebih memungkinkan peserta didik untuk membentuk karakternya sebagai generasi yang "melek media". Akan tetapi, fungsi guru sebagai fasilitator belum dijalankan sepenuhnya di SD N Gunungsaren khususnya dikelas III. SD N Gunungsaren merupakan salah satu institusi sekolah dasar yang terletak di kampung Gunungsaren Lor, Trimurti, Srandakan, Bantul, Yogyakarta. Meskipun institusi ini telah mendapatkan nilai akreditasi A, akan tetapi pembelajaran IPA di kelas III di SD N Gunungsaren berjalan dengan monoton, guru dalam menjelaskan mata pelajaran IPA hanya menggunakan metode ceramah, tanya jawab, dan penugasan. $^{3}$

Hasil observasi yang peneliti lakukan di SD N Gunungsaren menunjukkan bahwa metode pembelajaran yang dilaksanakan guru masih monoton, atau bisa dikatakan guru masih memegang peranan aktif dalam pembelajaran IPA di kelas III. Guru menyampaikan materi pembelajaran IPA tidak menggunakan media pembelajaran, padahal pelajaran IPA memiliki banyak pilihan media yang dapat digunakan. Selain itu saat pembelajaran IPA di kelas III berlangsung,

${ }^{1}$ Ngalim Purwanto, Ilmu Pendidikan dan Praktis, (Bandung, PT Remaja Rosdakarya: 2009), hlm. 36

${ }^{2}$ Suyadi, Strategi Pembelajaran Pendidikan Berkarakter, (Bandung, PT Remaja Rosdakarya: 2013), hlm. 17

${ }^{3}$ Kasmiyati, Guru Pengampu Mata Pelajaran IPA Kelas III B SD N Gunungsaren, wawancara tanggal 10 Agustus 2015 tampak bahwa minat belajar siswa masih rendah. Hal ini terlihat saat guru menjelaskan materi, banyak siswa yang asyik mengobrol dengan temannya. Saat guru bertanya kepada siswa, banyak siswa yang tidak menjawab, hanya ada satu dua siswa yang menjawab itupun karena mereka duduk di meja paling depan, selebihnya mereka asyik dengan aktivitasnya masing-masing. Hasil ulangan IPA kelas III A dan III B juga belum optimal. Siswa Kelas III A yang mendapatkan nilai lebih dari KKM ada 4 siswa dari 27 siswa, artinya siswa yang telah mencapai KKM sebesar 14,8\%, Sedangkan kelas III B dengan siswa berjumlah 22, semuanya memiliki nilai kurang dari KKM. ${ }^{4}$

Dari fakta-fakta di atas, maka harus ada inovasi dalam model pembelajaran IPA kelas III di SD N Gunungsaren. Menurut Soekamto, dkk mereka mengemukakan bahwa model pembelajaran adalah "Kerangka konseptual yang melukiskan prosedur yang sistematis dalam mengorganisasikan pengalaman belajar untuk mencapai tujuan belajar tertentu, dan berfungsi sebagai pedoman bagi para perancang pembelajaran dan para pengajar dalam merencanakan aktivitas belajar mengajar". Jadi model pembelajaran adalah suatu kerangka atau arah bagi pengajar atau guru untuk mengajar agar tujuan pembelajaran dapat tercapai. Salah satu jenis model pembelajaran adalah pembelajaran kooperatif.

Pembelajaran kooperatif merupakan strategi pembelajaran kelompok yang dapat meningkatkan prestasi belajar peserta didik, sekaligus dapat meningkatkan kemampuan hubungan sosial, menumbuhkan sikap menerima kekurangan diri dan orang lain serta dapat meningkatkan harga diri. Pembelajaran kooperatif juga dapat dikatakan suatu model pembelajaran yang menggunakan sistem pengelompokan atau tim kecil (empat sampai enam peserta didik) dengan latar belakang kemampuan akademik, jenis kelamin, ras, atau suku yang berbeda. ${ }^{6}$

${ }^{4}$ Hasil observasi kelas III B dan IIIA yang dilakukan pada tanggal 10 dan 15 Agustus 2015

${ }^{5}$ Trianto, Mendesain Model Pembelajaran InovatifProgersif, (Jakarta : Kencana Prenada Media Group, 2009), hlm. 22

${ }^{6}$ Suyadi, Strategi Pembelajaran..., hlm. 62 
Pembelajaran kooperatif ini banyak sekali macamnya salah satunya adalah Numbered Head Together (NHT). Pembelajaran kooperatif Numbered Head Together (NHT) merupakan jenis pembelajaran kooperatif yang mempengaruhi interaksi siswa, dan sebagai pilihan untuk kelas tradisional. Numbered Head Together (NHT) ini dikembangkan pertama kali oleh Spenser Kagen pada tahun 1993, untuk melibatkan banyak siswa dalam menelaah materi pembelajaran dan juga digunakan dalam mengecek pemahaman siswa setelah materi pembelajaran sudah disampaikan. Dalam mengaplikasikan pembelajaran koopertif Numbered Head Together (NHT) ini maka berikut fase-fasenya: penomoran, mengajukan pertanyaan, berfikir bersama, dan menjawab. ${ }^{7}$

Dengan mengkaji karakteristik dan keunggulan model pembelajaran kooperatif tipe Numbered Head Together (NHT) ini diduga dapat mengatasi masalah rendahnya hasil belajar siswa kelas III di SD N Gunungsaren. Model pembelajaran kooperatif tipe Numbered Head Together (NHT) ini mengutamakan keterlibatan dalam pembelajaran sehingga menguatkan pemahaman siswa, dan diharapkan dapat efektif sehingga hasil belajar IPA siswa kelas III di SD N Gunungsaren akan lebih baik.

Berdasarkan penjelasan di atas, maka peneliti merumuskan masalah sebagai berikut:

Apakah terdapat perbedaan hasil belajar IPA kelas III di SD N Gunungsaren antara pembelajaran yang menggunakan model pembelajaran kooperatif tipe Numbered Head Together (NHT) dengan pembelajaran model konvensional?

Bagaimanakah efektivitas pembelajaran kooperatif tipe Numbered Head Together (NHT) terhadap hasil belajar IPA siswa kelas III di SD N Gunungsaren?

\section{METODE PENELITIAN Jenis Penelitian}

Jenis penelitian ini merupakan penelitian eksperimen. Metode penelitian yang peneliti gunakan adalah metode eksperimen. Penelitian ini akan menguji efektifitas penggunaan model

${ }^{7}$ Trianto, Mendesain Model Pembelajaran InovatifProgresif, (Jakarta, Kencana Prenada Media Group: 2009), hlm. 82 pembelajaran kooperatif tipe Numbered Head Together (NHT) terhadap hasil belajar pada pembelajaran Ilmu Pengetahuan Alam (IPA) di SD N Gunungsaren Srandakan Bantul. Untuk menguji efektifitas maka peneliti akan menggunakan dua kelas yakni kelas eksperimen dan kelas kontrol dengan memberikan pre-test dan post-test terhadap dua kelas tersebut, untuk mengetahui hasil belajar.

\section{Desain Penelitian}

Desain penelitian yang ingin digunakan oleh peneliti adalah quasi experimental design. Peneliti akan menggunakan salah satu desain quasi eksperimen yaitu Non-equivalent control group design.

\section{Populasi dan Sampel Penelitian}

Populasi pada penelitian ini adalah seluruh siswa kelas III di SD Negeri Gunungsaren. Sampel dari penelitian ini adalah siswa kelas III B yang memperoleh model pembelajaran kooperatif tipe Number Head Together (NHT) dan siswa kelas III A yang memperoleh model pembelajaran konvensional.

\section{Tempat dan Waktu Penelitian}

Tempat Penelitian ini akan bertempat di SD N Gunungsaren Srandakan Bantul Yogyakarta, dan akan dilaksanakan bulan November tahun 2015 semester ganjil pada tahun pelajaran 2015/2016, penelitian ini dilaksanakan sebanyak 3 kali pertemuan untuk setiap kelas eksperimen dan kelas kontrol.

\section{Variabel Penelitian}

Variabel peneliti dalam penelitian ini terdapat 2 variabel, yaitu:

Variabel Independent (variabel bebas) dalam penelitian ini model pembelajaran kooperatif tipe Numbered Head Together (NHT).

Variabel dependen (variabel terikat) dalam penelitian ini hasil belajar IPA kelas III di SD N Gunungsaren.

\section{Teknik dan Instrumen Pengumpulan Data}

Dalam penelitian ini teknik pengumpulan data yang akan digunakan oleh peneliti adalah sebagai berikut: 
Tabel 1 Kisi-Kisi Soal Pre-test dan Post-test

\begin{tabular}{|c|c|c|c|c|}
\hline SK & KD & Indikator & $\begin{array}{c}\text { No Item } \\
\text { soal PG }\end{array}$ & $\begin{array}{c}\text { Jumlah } \\
\text { Soal }\end{array}$ \\
\hline \multirow{7}{*}{$\begin{array}{l}\text { 2.Memahami } \\
\text { kondisi lingkungan } \\
\text { yang berpengaruh } \\
\text { terhadap kesehatan } \\
\text { dan upaya menjaga } \\
\text { kesehatan lingkungan }\end{array}$} & 2.1.Membedakan ciri-ciri & 2.1.1.Menjelaskan lingkungan sehat & $1,2,3$ & 3 \\
\hline & lingkungan sehat dan & 2.1.2.Menjelaskan lingkungan tidak sehat & $4,5,6$ & 3 \\
\hline & lingkungan tidak sehat & 2.1.3.Membedakan ciri-ciri lingkungan sehat dan & $7,8,9$ & 3 \\
\hline & berdasarkan pengamatan & lingkungan tidak sehat berdasarkan pengamatan & & \\
\hline & 2.2.Mendeskripsikan & 2.2.1. Menjelaskan pengaruh kondisi lingkungan & $10,11,12$ & 3 \\
\hline & kondisi lingkungan yang & sehat terhadap kesehatan & & \\
\hline & $\begin{array}{l}\text { berpengaruh terhadap } \\
\text { kesehatan }\end{array}$ & $\begin{array}{l}\text { 2.2.2. Menjelaskan pengaruh kondisi lingkungan } \\
\text { tidak sehat terhadap kesehatan }\end{array}$ & $13,14,15$ & 3 \\
\hline Jumlah soal & & & & 15 soal \\
\hline
\end{tabular}

Tes

Tes adalah untuk mengukur ada atau tidaknya serta besarnya objek atau subyek yang diteliti. ${ }^{8}$ Dalam tes ini peneliti akan mengukur kemampuan kognitifnya untuk memperoleh hasil belajar pada mata pelajaran IPA di kelas III SD N Gunungsaren. Tes yang digunakan peneliti yaitu tes pre-test dan post-test, yang akan dilakukan di kelas eksperimen (III B) dan kelas kontrol (III A).

\section{Observasi}

Observasi (observation) merupakan teknik pengumpulan data yang artinya mengumpulkan data atau menjaring data dengan melakukan pengamatan terhadap subyek dan atau obyek penelitian secara seksama (cermat dan teliti) dan sistematis. ${ }^{9}$

Dengan melakukan observasi ini maka peneliti akan melakukan pengamatan terhadap subyek penelitian (kelas III di SD N Gunungsaren) dengan cermat dan teliti. Metode ini digunakan untuk memperoleh data bagaimana proses pembelajaran di SD N Gunungsaren, dan juga untuk memperoleh data apakah peneliti melaksanakan model pembelajaran kooperatif tipe Numbered Head Together (NHT) sesuai dengan rencana pelaksanaan pembelajaran.

\section{Dokumentasi}

Teknik dokumentasi yaitu mencari data mengenai hal-hal atau variabel yang berupa catatan, transkrip, buku, surat kabar, majalah,

${ }^{8}$ Suharsimi Arikunto, Prosedur Penelitian..., hlm.266

${ }^{9}$ Supardi, Metode Penelitian Ekonomi \& Bisnis, (Yogyakarta, UII Press: 2005), hlm. 136 prasasti, notulen rapat, lengger, agenda, dan sebagainya. ${ }^{10}$

Dalam penelitian ini peneliti akan menggunakan dokumentasi untuk mendapatkan data-data yang berkaitan dengan SD N Gunungsaren yang diperlukan peneliti. Metode ini digunakan untuk memperoleh data gambaran umum sekolah SD N Gunungsaren, nilai ulangan siswa, suasana kelas yang menggunakan model pembelajaran kooperatif tipe Numbered Head Together (NHT) dan wawancara kepada guru.

Dalam penelitian ini instrumen pengumpulan data yang akan digunakan oleh peneliti yaitu sebagai berikut:

\section{Test}

Tes yang akan dilaksanakan dalam penelitian ini ada dua yaitu: pre-test dan post-test. Pre-test dilaksanakan pada awal pembelajaran dan posttest dilaksanakan pada akhir pembelajaran untuk evaluasi. Test ini digunakan untuk mengetahui hasil belajar siswa kelas III yang menggunakan model pembelajaran kooperatif tipe Numbered Head Together (NHT) dan yang tidak menggunakan model pembelajaran kooperatif tipe Numbered Head Together (NHT).

Tabel 1 Kisi-kisi soal pre-test dan post-test yang akan disampaikan:

\section{Lembar Observasi}

Instrumen yang digunakan oleh peneliti dalam observasi yaitu lembar observasi. Lembar observasi digunakan untuk mencatat dan menilai bagaimana peneliti melakukan penelitian

${ }^{10}$ Suharsimi Arikunto, Prosedur Penelitian..., hlm. 274 
dengan mengajar mata pelajaran IPA, dengan menggunakan pembelajaran kooperatif tipe Numbered Head Together (NHT) kelas III di SD $\mathrm{N}$ Gunungsaren dan menggunakan metode konvesional.

Dalam penelitian ini lembar observasi ini diberikan kepada kelas eksperimen dan kelas kontrol, dan yang diminta untuk mengisi lembar observasi adalah guru mata pelajaran IPA SD N Gunungsaren kelas III A adalah Ibu Ana Woro Naningtyas, S.Pd. SD dan III B Ibu Kasmiyati, S. Pd.

\section{Dokumentasi}

Dokumentasi ini digunakan untuk mengetahui bagaimana kegiatan pembelajaran di kelas saat pembelajaran IPA dengan model pembelajaran kooperatif tipe Numbered Head Together (NHT) diterapkan di kelompok eksperimen, dan juga akan digunakan untuk kelompok kontrol.Sedangkan dokumentasi ini juga digunakan untuk mengetahui data sekolah, seperti gambaran umum sekolah SD N Gunungsaren nilai ulangan siswa, dan lain-lain.

\section{Keabsahan Data}

Dalam keabsahan data ini peneliti menggunakan uji validitas dan uji reliabilitas.

\section{Uji Validitas}

Uji validitas peneliti menggunakan validitas isi dan validitas kontruk. Validitas isi dilakukan dengan membandingkan antara isi instrument dengan materi pelajaran yang telah diajarkan. ${ }^{11}$ Soal yang di validitas isi 25 soal, dan yang menjadi validator adalah dua dosen STIA Universitas Alma Ata, yaitu Ibu Laelatul Badriah, M.Pd dan Ibu Martalia Ardyaningrum, M.Pd.

Validitas konstruk dilakukan di MI Ma'arif Kadipolo dan SD Muhammadiyah Bendo, dan penghitungannya dengan rumus product moment dengan bantuan SPSS 16. Dari 25 soal yang di uji coba di dua instansi sekolah tersebut didapatkan hasil 15 valid dan 10 tidak valid.

\section{Uji Reliabilitas}

Uji reliabilitas pada penelitian ini menggunakan Kuder Richardson, dengan hasil

${ }^{11}$ Sugiyono, Statistik untuk..., hlm. 353 $r_{\text {hitung }} 0,845$ sedangkan nilai ${ }^{r_{\text {tabel }}}$ 0,325. Maka dapat disimnulkan bahwa ${ }_{\text {hitung }}$ lebih besar daripada $r_{\text {tabel }}$, sehingga instrument test yang digunakan oleh peneliti dapat dikatakan reliabel.

\section{Pengolahan dan Analisis Data}

Dalam penelitian pengolahan dan analisis data menggunakan uji prasyarat dan teknik analisis data.

\section{Uji prasyarat}

Uji prasyarat menggunakan uji normalitas dan uji homogenitas.

Uji normalitas

Dalam perhitungan yang dilakukan peneliti dengan menggunakan kolmogorov dengan bantuan SPSS 16 maka didapatkan hasil nilai p kelas eksperimen $=0,012$ dan $\mathrm{p}$ kelas kontrol $=0,032$, jadi $\mathrm{p}<0,05$ maka dapat disimpulkan bahwa dua kelas tersebut dinyatakan tidak normal. Karena persyaratan data disebut normal jika probilitas atau $\mathrm{p}>0,05$ pada uji normalitas dengan menggunakan Kolmogorov Smirnov. ${ }^{12}$

\section{Uji homogenitan}

Untuk menguji homogenitas peneliti akan menggunakan rumus uji $\mathrm{F}$, dengan taraf kesalahan sebesar 5\%, rumus uji $\mathrm{F}$. F diketahui dengan membagi antara varians terbesar dibagi $f_{\text {hitung }}$ terkecil. Kotontuan dari uji F ini bila harga $<$ atau $=f_{\text {tabel }}$, maka Ho diterima dan Ha ditolak.

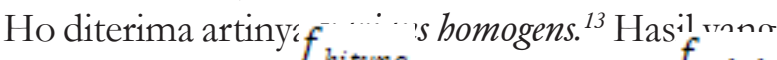
didafatronn adalah hitung 1,88 sedangkan $f_{\text {tabel }}$ $1,99, f_{\text {tabel }}$ diketahui dengan cara $\mathrm{dk}$ pembilang $=$ $(27-1)$ dan dk penyebut $=(22-1)$. Berdasarkan $\mathrm{dk}$ pembilang $=26 \mathrm{dan}$ penyebut $=21$, dengan ta $\mathrm{rnf}$ kesalahan ditetapkan $=5 \%$, maka harga $f_{\text {tabel }}=1,99$.

$f_{\text {hitung }}$ nalam hal ini berlaku ketentuan, bil h hnroga hitung lebih kecil atau sama dengan $f_{\text {tabel }}$ ( $\left.D_{h}: F_{t}\right)$, maka Ho diterima dan Ha ditolak. Ho diterima artif ianc hnmogen. ${ }^{14}$ Dalam perhitungan ini hitung $<f_{\text {tabel }}, 1,88<1,99$,

${ }^{12}$ Triton, SPSS 13.0 Terapan Riset Parametik Statistik Terapan, (Yogyakarta, Andi Offset : 2006), hlm.79

${ }^{13}$ Sugiyono, Statistik untuk..., hlm. 140-141

${ }^{14}$ Ibid., hlm. 141 
maka Ho diterima dan $\mathrm{Ha}$ ditolak, dan $\mathrm{Ho}$ diterima artinya varians homogen.

\section{Analisis Data}

Dalam teknik analisis data ini peneliti menggunakan hipotesis komparatif dua sampel yang tidak berpasangan atau independen. Jadi untuk menguji hipotesis yang 1 peneliti menggunakan uji Mann-Whitney U-Test, dengan bantuan SPSS 16. Dengan kaidah pengambilan keputusan jika nilai Fract Sig. (1-tailed) kurang dari atau sama dengan ${ }^{\alpha}(0,05)$ maka Ho ditolak dan Ha diterima, dan jika Exact Sig. (1-tailed) lebih dari $\alpha_{(0,05)}$ maka Ho dierima dan Ha ditolak. ${ }^{15}$

Untuk menguji hipotesis 2 menggunakan hasil belajar di kelas eksperimen dan kelas kontrol. Dengan kaidah pengambilan leseputusan jika nilai presentase ketuntasan siswa $\geq 95 \%$ dari jumlah siswa maka $\mathrm{Ho}_{2}$ ditolak dan $\mathrm{Ha}_{2}$ diterima. Jika persentase ketuntasan siswa $<95 \%$ dari jumlah siswa maka $\mathrm{Ho}_{2}$ diterima dan $\mathrm{Ha}_{2}$ diterima.

Hipotesis statistik

Hipotesis Statistik, dalam penelitian ini adalah:

$$
\begin{aligned}
& \mathrm{Ho}_{1}: \mu 1_{1}=\mu 2_{1} \\
& \mathrm{Ha}_{1}: \mu 1_{1} \neq \mu 2_{1} \\
& \mathrm{Ho}_{2}: \mu 1_{2} \geq \mu 2_{2} \\
& \mathrm{Ha}_{2}: \mu 1_{2}<\mu 2_{2}
\end{aligned}
$$

Artinya :

$\mathrm{Ho}_{1}$ : tidak terdapat perbedaan hasil belajar antara kelas yang menggunakan model pembelajaran kooperatif tipe Numbered Head Together (NHT) dengan kelas yang konvesional.

$\mathrm{Ha}_{1}$ :terdapat perbedaan hasil belajar antara kelas yang menggunakan model pembelajaran kooperatif tipe Numbered Head Together (NHT) dengan kelas konvesional.

$\mathrm{Ho}_{2}$ : Persentase ketuntasan siswa $<95 \%$ dari jumlah siswa

$\mathrm{Ha}_{2}$ : Persentase ketuntasan siswa $\geq 95 \%$ dari jumlah siswa

${ }^{15}$ Wahid Sulaiman, Statistik Non-Parametrik Contoh Kasus dan Pemecahannya dengan SPSS, (Yogyakarta, Andi Offset: 2005), hlm. 31
Keterangan:

$\mu 1_{1}=$ hasil belajar siswa kelas III pada pembelajaran IPA dengan menggunakan model pembelajaran kooperatif tipe Numbered Head Together (NHT).

$\mu 2_{1}=$ hasil belajar siswa kelas III pada pembelajaran IPA tidak menggunakan model pembelajaran kooperatif tipe Numbered Head Together (NHT).

$\mu 1_{2}=$

presentase ketuntasan siswa di kelas yang menggunakan model pembelajaran kooperatif tipe Numbered Head Together (NHT) atau di kelas konvesional.

$$
\mu 2_{2}=\text { dari jumlah siswa di kelas yang }
$$
menggunakan model pembelajaran kooperatif tipe Numbered Head Together (NHT) atau di kelas konvesional.

\section{HASIL PENELITIAN DAN PEMBAHASAN}

Penelitian ini dilakukan dengan memberikan pembelajaran IPA sebanyak dua kali pertemuan untuk masing-masing kelas eksperimen dan kelas kontrol. Pembelajaran IPA dilakukan sebagai treatment (perlakuan) pada masing-masing kelas yang telah ditentukan sebagai sampel. Selanjutnya dilakukan post-test untuk mengetahui kemampuan kognitif siswa di kelas eksperimen dan kontrol.

Pembelajaran IPA dengan menggunakan model pembelajaran kooperatif tipe Numbered Head Together (NHT) merupakan suatu model pembelajaran yang mengelompokan siswa secara heterogen. Yang dimaksud heterogen adalah dalam membentuk kelompok harus memperhatikan tingkat kemampuan siswa, jenis kelamin siswa, dan suku ras siswa kalau berbeda. Pada awal pembelajaran kooperatif tipe Numbered Head Together (NHT), peneliti menyampaikan materi pembelajaran tentang lingkungan. Setelah itu, dibentuk kelompok secara heterogen. Setelah dikelompokkan, peneliti memberikan nomor kepada seluruh anggota siswa, nomor yang diberikan itu berbeda-beda. Selanjutnya siswa mengerjakan soal atau mengajukan pertanyaan, berpikir bersama, dan terakhir menjawab. Dengan pendampingan guru, siswa diminta untuk memahami setiap soal beserta jawabannya, dikarenakan setiap anggota kelompok mempunyai kesempatan yang sama untuk 
menjawab. Berikut peneliti akan jabarkan hasil tes pada kelas Eksperimen dan Kelas Kontrol:

\section{Tabel 2. Hasil Belajar IPA Kelas Eksperimen dan Kelas Kontrol}

\begin{tabular}{lcccc}
\hline & Kelas & \multicolumn{2}{c}{$\begin{array}{c}\text { Kelas } \\
\text { Eksperimen }\end{array}$} & \multicolumn{2}{c}{ Kelas Kontrol } \\
\cline { 2 - 5 } Deskriptif & Pretest & Post-test & Pretest & Posttest \\
\hline $\mathrm{N}$ & 22 & 22 & 27 & 27 \\
\hline Median & 88,5 & 100 & 80 & 93 \\
Modus & 87 & 100 & 93 & 93 \\
Standar Deviasi & 21,18 & 6,17 & 29,06 & 20,77 \\
Rata-rata & 86 & 95 & 75 & 86 \\
Nilai $\geq$ KKM 75 & 19 & 22 & 19 & 21 \\
Nilai < KKM 75 & 3 & 0 & 8 & 6 \\
\hline
\end{tabular}

Berdasarkan tabel 2, dapat diketahui bahwa pada bagian nilai pre test sebanyak 19 siswa telah mencapai nilai di atas KKM dan sebanyak 3 siswa belum mencapai nilai KKM. Jika dipersentasekan, sebesar 13,64\% belum mencapai KKM dan sebesar 83,36 \% telah mencapai KKM. Sedangkan pada bagian kolom nilai post test dapat diketahui bahwa sebanyak 22 siswa telah mencapai KKM dan sebanyak 0 siswa belum mencapai KKM. Jika dipersentasekan sebesar $0 \%$ belum mencapai KKM dan sebesar 100\% telah mencapai KKM.

Sedangkan pada kelas kontrol dapat diketahui bahwa pada bagian nilai pre test sebanyak 19 siswa telah mencapai nilai di atas KKM dan sebanyak 8 siswa belum mencapai nilai KKM. Jika dipersentasekan sebesar 29,63\% belum mencapai KKM dan sebesar 70,37\% telah mencapai KKM. Sedangkan pada bagian kolom nilai post test dapat diketahui bahwa sebanyak 21 siswa telah mencapai KKM dan sebanyak 6 siswa belum mencapai KKM. Jika dipresentasekan sebesar 22,22\% belum mencapai KKM dan sebesar 77,78\% telah mencapai KKM.

Dari hasil instrument test yang peneliti ujikan didapatkan bahwa terjadi peningkatan hasil post-test pada kelas eksperimen dan kelas kontrol. Pada awal pelaksanaan di kelas eksperimen terjadi peningkatan dengan nilai rata-rata pre-test 86 dan rata-rata post-test 95 , sedangkan untuk kelas kontrol terjadi peningkatan dengan nilai rata-rata pre-test 75 dan rata-rata post-test 86.

\section{Hasil Uji Mann-Whitney U-test}

Analisis data kuantitatif yang digunakan dalam penelitian adalah uji Mann-Whitney U-test. $\mathrm{Hal}$ ini dikarenakan, hipotesis peneliti termasuk hipotesis komparatif dua sampel independen dan data yang diperoleh tidak berdistribusi normal. Hipotesis penelitian dengan menggunakan Uji Mann-Whitney U-test adalah sebagai berikut:

$\mathrm{Ho}_{1}$ : tidak terdapat perbedaan hasil belajar antara kelas yang menggunakan model pembelajaran kooperatif tipe Numbered Head Together (NHT) dengan kelas yang konvesional.

$\mathrm{Ha}_{1}$ : terdapat perbedaan hasil belajar kelas yang menggunakan model pembelajaran kooperatif tipe Numbered Head Together (NHT) dengan kelas yang konvesional.

Hasil uji Mann-Whitney U-test dengan menggunakan program SPSS 16 dapat dilihat pada tabel 3 .

Tabel 3. Hasil Uji Mann-Whitney U-test

Test Statistics

\begin{tabular}{lr}
\hline \multicolumn{2}{c}{ hasil_belajar } \\
\hline Mann-Whitney U & 203.000 \\
Wilcoxon W & 581.000 \\
$Z$ & -1.985 \\
Asymp. Sig. (2-tailed) & .047 \\
Exact Sig. (2-tailed) & .046 \\
Exact Sig. (1-tailed) & .023 \\
Point Probability & .000 \\
\hline a. Grouping Variable: model_pembelajaran
\end{tabular}

Jika nilai Fract Sig. (1-tailed) kurang dari atau sama dengan $\alpha(0,05)$ maka $\mathrm{Ho}_{1}$ ditolak dan $\mathrm{H}^{\wedge}$ diterima, dan jika Exact Sig. (1-tailed) lebih besar ${ }^{\alpha}$ $(0,05)$ maka $\mathrm{Ho}_{1}$ dierima dan $\mathrm{Ha}_{1}$ ditolak. ${ }^{16}$ Dari tabel test statistics di atas didapatkan bahwa nilai Exact Sig. (1-tailed) adalah 0,033. Nilai Exact Sig. (1-tailed) $=0,023$ kurang dari ${ }^{\alpha}(0,05)$ maka Ho$_{1}$ ditolak dan $\mathrm{Ha}_{1}$ diterima. Jadi terdapat perbedaan hasil belajar kelas yang menggunakan model pembelajaran kooperatif tipe Numbered Head Together (NHT) dengan kelas yang konvesional.

${ }^{16}$ Wahid Sulaiman, Statistik Non-Parametrik... hlm. 31 
Perbedaan Hasil Belajar IPA kelas III di SD N Gunungsaren antara Pembelajaran yang Menggunakan Model Pembelajaran Kooperatif Tipe Numbered Head Together (NHT) dengan Pembelajaran Model Konvensional.

Berdasarkan pada uji Mann-Whitney U-test dengan program SPSS 16 diperoleh hasil nilai Exact Sig. (1-tailed) adalah 0,023, karena hasil tersebut lebih kecil dari 0,05 maka $\mathrm{Ho}_{1}$ ditolak dan $\mathrm{Ha}_{1}$ diterima. Hal ini berdasarkan pada kriteria pengambilan keputusan sebagai berikut, jika nilai Exart Sig. (1-tailed) kurang dari atau sama dengan $\alpha(0,05)$ maka $\mathrm{Ho}_{1}$ ditolak dan $\mathrm{Ha}_{1}$ diterima, dan jika Exact Sig. (1-tailed) lebih besar ${ }^{\alpha}(0,05)$ maka $\mathrm{Ho}_{1}$ ditolak dan $\mathrm{Ha}_{1}$ diterima. ${ }^{17}$ Jadi terdapat perbedaan hasil belajar kelas yang menggunakan model pembelajaran kooperatif tipe Numbered Head Together (NHT) dengan kelas yang konvesional. Ini dilihat dari perolehan hasil belajar post-test dari kedua kelas tersebut, untuk kelas eksperimen bila presentasekan ada 100\% siswa yang memperoleh nilai lebih besar atau sama dengan KKM, sedangkan kelas kontrol bila dipresentasikan $77,78 \%$ siswa yang memperoleh nilai lebih besar atau sama dengan KKM.

Pada model pembelajaran kooperatif tipe Numbered Head Together (NHT) yang mempengaruhi interaksi antara anggota kelompok dan juga antara kelompok. Adanya interaksi ini maka diharapkan siswa dapat aktif dalam berdiskusi dan juga aktif dalam menjawab pertanyaan. ${ }^{18}$ Adanya penomoran untuk menganti nama siswa sehingga peneliti atau temannya dapat memilih nomor tanpa mengetahui siapa pemilik nomor tersebut, ini dikarenakan ada banyaknya siswa di kelas tersebut dan juga nomor siswa tidak ditempel dikepala, nomor siswa hanya berupa kartu nomor kecil yang akan diingat oleh setiap siswa.

Dalam model pembelajaran kooperatif tipe Numbered Head Together (NHT) ini dihadirkan dengan soal-soal yang dikerjakan bersamasama dalam satu kelompok, sehingga peneliti mengharapkan siswa dapat mampu berdiskusi atau adanya interaksi antar siswa. Siswa yang belum

\footnotetext{
${ }^{17}$ Ibid,. hlm.31

${ }^{18}$ Trianto, Mendesain Model Pembelajaran..., hlm. 82
}

paham dapat bertanya dengan temannya yang paham, sehingga dapat menambah pemahaman setiap siswa dalam memahami materi yang ada di soal-soal. Setiap siswa diharapkan untuk memahami semua jawaban tersebut. Sehingga berfikir bersama dapat meningkatkan pemahaman siswa karena adanya diskusi kelompok, melibatkan banyak siswa dalam menelaah materi pembelajaran, mengecek pemahaman siswa setelah materi pembelajaran sudah disampaikan, dan juga melatih siswa untuk bekerja sama dan menghargai pendapat teman dalam kelompok, dan lebih memotivasi siswa dalam belajar. ${ }^{19}$

Setelah siswa melakukan diskusi maka selanjutnya adalah menjawab soal, agar dapat memotivasi siswa untuk belajar. Dalam menjawab yang dipanggil adalah nomor siswanya, setiap siswa mempunyai peluang yang sama dalam menjawab pertanyaan, dalam pemanggilan nomor siswa ini dapat menyebabkan siswa aktif dalam menjawab, dan melatih siswa berani dalam menyampaikan pendapat dan berani bicara di depan kelas. ${ }^{20}$

\section{Efektifitas Model Pembelajaran Kooperatif} Tipe Numbered Head Together (NHT) terhadap hasil belajar siswa kelas III di SD N Gunungsaren

Penelitian ini dikatakan efektif apabila memenuhi dua kriteria keefektifan yang telah ditentukan peneliti sebelumnya yaitu:

1. Nilai rata-rata siswa pada pembelajaran IPA di atas nilai KKM yaitu 75.

Nilai rata-rata post-test kelas eksperimen dan kelas kontrol sudah mendapatkan nilai rata-rata di atas nilai KKM yaitu 75. Nilai rata-rata post-test kelas eksperimen 95 dan nilai rata-rata post-test kelas kontrol 86.

2. Siswa yang mendapat nilai di atas KKM minimal 95\% dari jumlah siswa.

Siswa yang mendapatkan nilai di atas KKM minimal 95\% dari jumlah siswa ini terdapat di kelas eksperimen. Kelas eksperimen pada posttest jumlah siswa yang mendapatkan nilai di atas KKM bila dipresentasikan ada 100\% dari jumlah

\footnotetext{
${ }^{19}$ Agus Awang Pamungkas, Pengarub Strategi Cooperative..., hlm. 13

${ }^{20}$ Ibid., hlm. 13
} 
siswa yang mendapatkan nilai di atas KKM. Untuk kelas kontrol siswa yang mendapatkan nilai di atas KKM bila dipresentasekan terdapat $77,78 \%$ dari jumlah siswa.

Oleh karena itu dapat disimpulkan bahwa kelas eksperimen atau kelas yang menggunakan model pembelajaran kooperatif tipe Numbered Head Together (NHT) efektif digunakan pada mata pelajaran IPA di SD N Gunungsaren karena telah memenuhi dua kriteria kefektifan di atas.

\section{KESIMPULAN}

Berdasarkan hasil penelitian dan pembahasan peneliti memperoleh kesimpulan penelitian sebagai berikut:

Terdapat perbedaan hasil belajar IPA kelas III di SD N Gunungsaren antara pembelajaran yang menggunakan model pembelajaran kooperatif tipe Numbered Head Together (NHT) dengan pembelajaran model konvensional. Hal ini ditunjukkan dari hasil uji Mann-Whitney U-Test. Hasil penelitian dengan menggunakan uji MannWhitney U-Test untuk post-test kelas eksperimen dan post-test kelas lontrol dengan nilai Exact Sig. (1-tailed) $0,023<{ }^{\alpha}(0,05)$, maka $\mathrm{Ho}_{1}$ ditolak dan $\mathrm{Ha}_{1}$ diterima.

Terdapat efektifitas model pembelajaran kooperatif tipe Numbered Head Together (NHT) terhadap hasil belajar IPA siswa kelas III di SD N Gunungaren. Hal ini dapat ditunjukkan bahwa terpenuhinya dua kriteria keefektifan model pembelajaran kooperatif tipe Numbered Head Together (NHT) di kelas eksperimen yaitu nilai rata-rata siswa pada pembelajaran IPA di atas nilai KKM yaitu 75 dan siswa yang mendapat nilai di atas KKM minimal 95\% dari jumlah siswa. Nilai rata-rata yang didapatkan di kelas eksperimen 95 dan terdapat $100 \%$ siswa yang mendapatkan nilai di atas KKM dari jumlah siswa.

\section{DAFTAR PUSTAKA}

Abbudin, Nata. 2009. Perspektif Islam tentang Strategi Pembelajaran. Jakarta: Kencana Achmad, Sugandi, dkk. 2000. Belajar dan Pembelajaran. Semarang: IKIP Press

Agus Awang, Pamungkas. 2014. Pengarub Strategi Cooperative Learning Tipe Numbered Head Together (NHT) Terhadap MInat Belajar dan
Prestasi Belajar pada Mata Pelajaran Ibadab SiswaKelas XI SMA Mubammadiyah Mlati Sleman Yogyakarta. Yogyakarta: Fakultas Ilmu Tarbiyah dan Keguruan Universitas Islam Sunan Kalijaga, Skripsi

Agus, Suprijono. 2009. Cooperative Learning Teori \& Aplikasi Paikem. Yogyakarta: Pustaka Pelajars

Ahmad, Susanto. 2013. Teori Belajar d Pembelajaran di Sekolah Dasar. Jakarta: Kencana Prenada Media Group

Aunurrahman. 2012. Belajar dan Pembelajaran. Bandung: Alfabeta

Bambang, Marhiyanto, Syamsul, Arifin. 1999. Kamus Lengakap 165.000.000. Solo: Buana Raya

Haryanto. 2004. Sains Untuk SD Kelas III. Jakarta: Erlangga

Heri, Gunawan. 2013. Kurikulum dan Pembelajaran Pendidikan Agama Islam. Bandung: Alfabeta Jamil, Suprihatiningrum. 2013. Strategi Pembelajaran Teori \& Aplikasi. Yogyakarta: Ar-Ruzz Media

Junaedi, dkk. 2008. Strategi Pembelajaran. Malang: LAPIS PGMI

Listiani, Lina, dkk. 2008. Ilmu Pengetabuan Alam 1. Surabaya: LAPIS-PGMI

Maestro. 2015. Ilmu Pengetahuan Alam Model Pembelajaran yang Meliputi Aspek Kompetensi Sikap, Pengetabuan, dan Keterampilan. Sukoharjo: CV Hasan Pratama

Miftahul, Huda. 2011. Cooperative Learning Metode, Teknik, Struktur dan Model Penerapan. Yogyakarta: Pustaka Pelajar

Muhammad Thobroni, Arif Mustofa. 2011. Belajar \& Pembelajaran Pengembangan Wacana dan Praktik Pembelajaran dalam Pembangunan Nasional. Yogyakarta: Ar-Ruzz Media.

Nana, Syaodih Sukmadinata. 2009. Metode Penelitian Pendidikan. Bandung: PT Remaja Rosdakarya.

Nasution. 2013. Metodologi Penelitian Naturalistik kualitatif. Bandung: Alfabeta.

Ngalim, Purwanto. 2009. Ilmu Pendidikan dan Praktis. Bandung: PT Remaja Rosdakarya.

Nur, Wahidah. 2013. Pengarub Penerapan Metode Numbered Head Together (NHT) Terbadap 
Minat dan Hasil Belajar IPA Biologi Siswa di MTs N Maguwoharjo. Yogyakarta: Fakultas Sains dan Teknologi Universitas Islam Negeri Sunan Kalijaga, Skripsi.

Parisa, Westa, dkk. 1980. Ensiklopedi Administrasi. Jakarta: H. Mas Agung.

Poerwadaminta. 2003. Kamus Besar Babasa Indonesia. Jakarta: Balai Pustaka.

Robert E, Slavin. 2009. Cooperative Learning Teori, Riset, dan Praktik. Bandung: Nusa Media.

Rusdi, Pohan. 2007. Metodologi Penelitian Pendidikan. Yogyakarta: Lanarka Publisher.

Rusman. 2012. Model-Model Pembelajaran Mengembangkan Profesionalisme Guru. Jakarta: PT Grafindo Persada.

Sugiyono. 2010. Metode Penelitian Pendidikan Pendekatan Kuantitatif Kualitatif dan RఠD. Bandung: Alfabeta. 2012. Statistika untuk Penelitian. Bandung: Alfabeta. -------. 2013. Statistik Nonparametris. Bandung: Alfabeta.

Suharsimi, Arikunto. 2013. Prosedur Penelitian Suatu Pendekatan Praktik. Jakarta: Rineka Cipta.
Supardi. 2005. Metode Penelitian Ekonomi \& Bisnis. Yogyakarta: UII Press.

Suyadi. 2013. Strategi Pembelajaran Pendidikan Berkarakter. Bandung: PT Remaja Rosdakarya. Trianto. 2009. Mendesain Model Pembelajaran Inovatif-Progresif. Jakarta: Kencana Prenada Media Group.

------. 2010. Model Pembelajaran Terpadu. Jakarta: PT Bumi Aksara.

Triton. 2006. SPSS 13.0 Terapan Riset Parametik Statistik Terapan. Yogyakarta: Andi Offset.

Umar. 2014. Upaya Meningkatkan Hasil Belajar Pada Mata Pelajaran Matematika Dengan Menggunakan Metode Kooperatif Tipe Numbered Head Together (NHT) Siswa Kelas II Madrasah Ibtidaiyah Mubammadiyab Krendetan Kecamatan Bagelan Kabupaten Purworejo. Yogyakarta: Fakultas Ilmu Tarbiyah dan Keguruan Universitas Islam Sunan Kalijaga, Skripsi.

Wahid, Sulaiman. 2005. Statistik Non-Parametrik Contob Kasus dan Pemecahannya dengan SPSS. Yogyakarta: Andi Offset Wina, Sanjaya. 2013. Penelitian Pendidikan Jenis Metode dan Prosedur. Jakarta: Kencana Prenada Media Group. 